\title{
Assesment of Superior Colliculus in Audiogenic Epilepsy-Prone Wistar Rats Using A Stereological Method
}

\section{Odyojenik Epilepsiye Yatkın Wistar Sıçanlarda Superior Kollikulusun Stereolojik Metotla Değerlendirilmesi}

\author{
Seval KELOĞLAN, ${ }^{1}$ Niyazi TAŞÇI, ${ }^{2}$ Süleyman KAPLAN, ${ }^{3}$ Cafer MARANGOZ ${ }^{2}$ \\ 'Department of Nursing, Amasya University School of Health, Amasya, Turkey \\ ${ }^{2}$ Department of Physiology, Ondokuz Mayıs University Faculty of Medicine, Samsun, Turkey \\ ${ }^{3}$ Department of Histology and Embryology, Ondokuz Mayıs University Faculty of Medicine, Samsun, Turkey
}

\section{Summary}

Objectives: Audiogenic seizures are generated in the brainstem and involve the inferior and superior colliculi in their expression. Aim of the present study was to estimate total number of neurons in the right and left superior colliculi in genetically audiogenic epilepsy-prone Wistar rats using stereological method.

Methods: Ten female Wistar rats, weighing 180 to $220 \mathrm{~g}$ each, were divided into 2 groups: control $(n=5)$ and audiogenic epilepsy ( $n=5)$ groups. Subjects were anesthetized with urethane $(1.25 \mathrm{~g} / \mathrm{kg}$, intraperitoneal) and $10 \%$ formalin was perfused through the left cardiac ventricle. Total number of neurons was estimated in the right and left superior colliculi in both groups using optical fractionator stereological method.

Results: Total number of neurons in the superior colliculi was statistically lower in the right side of group with epilepsy compared with same side of control group $(p<0.05)$. There was also a significant difference between right and left sides in the epilepsy group $(p<0.05)$.

Conclusion: It has been determined that cellular mechanisms have a significant role in audiogenic epilepsy. The fact that there were significantly fewer neurons in right superior colliculus of epilepsy group compared with control group suggests that this area is likely to be influential on triggering the onset of seizure activity.

Keywords: Audiogenic seizure; epilepsy; stereological method; superior colliculus.

\section{Özet}

Amaç: Odyojenik nöbet beyin sapından kaynaklanır ve odyojenik nöbet ağında inferior ve superior kollikuluslar rol alır. Sunulan çalışmada amacımız genetik olarak odyojenik epilepsiye yatkın Wistar sıçanların sağ ve sol superior kollikulusda bulunan toplam nöron sayısının stereolojik metot ile bulunmasıdır.

Gereç ve Yöntem: Ağırlıkları 180-220 gr olan on dişi Wistar sıçan kontrol $(n=5)$ ve epilepsi $(n=5)$ olmak üzere iki gruba ayrıldılar. Sıçanların hepsi üretan (1.25 g/kg; i.p) ile anesteziye alındılar ve sol kardiyak ventrikülden \%10'luk formalin ile perfüze edildiler. Sağ ve sol superior kollikulusda bulunan toplam nöron sayısı stereolojik optik parçalama metodu kullanılarak hesaplandı.

Bulgular: Toplam nöron sayısı epilepsi sağ grubunda kontrol grubuna göre anlamlı ölçüde daha az bulundu ( $p<0.05)$. Epilepsi sağ ve epilepsi sol grupları arasında da toplam nöron sayısında anlamlı fark bulundu $(p<0.05)$.

Sonuç: Odyojenik epilepside hücresel mekanizmalar önemli rol oynamaktadır. Sağ superior kollikulusda nöron sayısının kontrole göre anlamlı ölçüde az olması, nöbet aktivitesinin başlamasında bu alanın etkili olabileceğini düşündürmektedir.

Anahtar sözcükler: Odyojenik nöbet; epilepsi; stereolojik metot; superior kollikulus.

Submitted (Geliş): 03.08.2016

Accepted (Kabul) : 13.12.2016

Correspondence (illetişim): Seval KELOĞLAN, M.D. e-mail (e-posta): sevallkeloglan@hotmail.com 


\section{Introduction}

Audiogenic seizure as an animal model of generalized tonic clonic seizures is induced with prolonged exposure to high levels of acoustic stimuli. ${ }^{[1]}$ In audiogenic seizures, the brainstem demonstrates activation with initial activation occurring in the inferior colliculus. ${ }^{[2]}$ During audiogenic seizure, the cochlear nucleus, lateral lemniscus, inferior colliculus, deep layer of superior colliculus, pontine reticular formation (PRF), and periaquaductal gray matter (PAG) assume functional roles and constitute important components of seizure network. ${ }^{[3,4]}$

Audiogenic seizure is divided into 3 behavioral phases: wild running, clonus, and tonus, and characteristic postictal behaviors may follow these phases. It has been suggested that brainstem nucleus plays a dominant role in emerging convulsive behavior. ${ }^{[5]}$ In clonic-tonic phases of audiogenic seizure, PAG and PRF are foremost, during wild running phase, deep layer of the superior colliculus leads, and during postictal depression phase, PRF plays dominant role. ${ }^{[6]}$

Many studies cited in the literature have demonstrated presence of correlation between superior colliculus and audiogenic seizure. ${ }^{[7,8]}$ In electrophysiological studies, 1 to 2 seconds before onset of wild running, explosive discharge from deep layers of superior colliculus has been detected. ${ }^{[5,9]}$ Chemical and electrical stimulation of deep layers of superior colliculus induces wild running behavior. Intensity of stimulus arising from deep layers of superior colliculus required to initiate wild running is lower than stemming from inferior colliculus. ${ }^{[5,10]}$ Lesion induced in superior colliculus suppresses severity of audiogenic seizure in genetically epilepsy-prone rats. ${ }^{[4]} A$ study performed with gammaaminobutyric acid (GABA) agonist muscimol and antagonist bicuculline in audiogenic Wistar rats have demonstrated proconvulsive effects of the posterior part in deep layers of superior colliculus. ${ }^{[11]}$ Despite many studies that have demonstrated association between audiogenic seizure and superior colliculus in seizure-prone Wistar rats, no stereological study to investigate any difference in number of neurons in the right and left superior colliculi has been been performed previously. As wistar rats are prone to epilepsy, they have been used in this study to determine the total number of neurons in the right and left superior colliculi, which are regarded as important structural components in the audiogenic network.

\section{Materials and Methods}

Genetically audiogenic epilepsy-prone Wistar rats were obtained from Ondokuz Mayıs University Experimental Animal Research Center. Ethical principles for use of experimental animals were observed. The subjects were housed at mean ambient temperature of $20 \pm 2^{\circ} \mathrm{C}$ with 12 hour alternate dark and light conditions. Rat chow pellets and water were available ad libitum.

For audiogenic seizure test, rats were placed in acrylic cages measuring $40 \times 40 \times 40 \mathrm{~cm}$, and exposed to 110 to $120 \mathrm{~dB}$ acoustic stimuli for 90 seconds. Using digital chronometer, onset and termination of first and second episode of wild running, and onset of tonic-clonic seizures were recorded. Convulsive behaviors were classified in compliance with previously defined method..$^{[12]}$

Five female Wistar rats weighing 180 to $220 \mathrm{~g}$ each constituted control group, and epilepsy group comprised 5 female Wistar rats that passed audiogenic seizure test. All subjects received intraperitoneal urethane $(1.25 \mathrm{~g} / \mathrm{kg})$ anesthesia, and $10 \%$ formaldehyde was perfused through left cardiac ventricle. Immediately after perfusion, animals were decapitated and brains were placed in special bottles containing formaldehyde. Following standard histological tissue procedures, brain tissue was blocked in Paraplast (Leica Biosystems $\mathrm{GmbH}$, Wetzlar, Germany) tissue embedding medium. Embedded tissue samples were properly placed on Lipshaw type rotary microtome. From sagittal plane, 40 $\mu \mathrm{m}$-thick tissue sections were cut and stained with cresyl violet. Following staining procedure, sections were covered with coverslip using Entellan (Merck KGaA, Darmstadt, Germany) mounting medium and left to dry. ${ }^{[13]}$

Total number of neurons in the right and left superior colliculi was calculated using optical fractionator stereological method. Basic logic of this method is to optically section target substance and count particles within systematically random sampled sections. Result is multiplied by fragmentation coefficient in order to find total number. That is, intended measurement (i.e., cell count) of subset with known proportion is performed, and total quantitative analysis is calculated by extrapolating this value to total. ${ }^{[14]}$

Prior to cell counting, standard borders of superior colliculi were determined using stereotaxic atlas. Area adjacent to 
inferior colliculus, pretectal nucleus, PAG, and nerve fibers, which pale yellow appearance with Nissl dye, was demarcated (Figure 1).

Thickness of sections decreased from $40 \mu$ to $20-25 \mu$ after they were mounted on coverslips, stained, and covered with glass slides. In compliance with predetermined procedural steps of optical fractionator method ( $x=300 \mu \mathrm{m}$; $y=300 \mu \mathrm{m})$, entire tissue section was meticulously analyzed, and at randomly and unbiasedly determined points, cell count was performed. In order to obtain at least $10 \mathrm{sec}$ tions required for optical fragmentation, section sampling fraction (SSF) was determined to be $1 / 2$. In other words, if we use 1 of every 2 sections, minimum of 20 sections was required. Superior colliculi were observed in between 19 and 23 sagittal sections of each hemisphere. Total number of sections obtained from each rat brain varied between 38 and 46. Area of superior colliculus determined for neuron count was magnified using immersion oil and was examined under microscope at 100x magnification. The image was transferred to monitor of computerized system, and neurons within unbiased counting frame were counted.

Three-dimensional optical dissector cell counting method uses $x$ and $y$ axes, and certain depth, $z$. Area $\left(400 \mu \mathrm{m}^{2}\right)$ in which cell count was to be performed was marked. Cell count within each area was calculated according to relevant formula. Step lengths $(x, y)$ were determined to be $300 \times 300$ $\mu \mathrm{m}$. In all counts, height of dissector probe (15 $\mu \mathrm{m})$, approximate area of unbiased counting frame $\left(1467.262 \mu \mathrm{m}^{2}\right)$, and

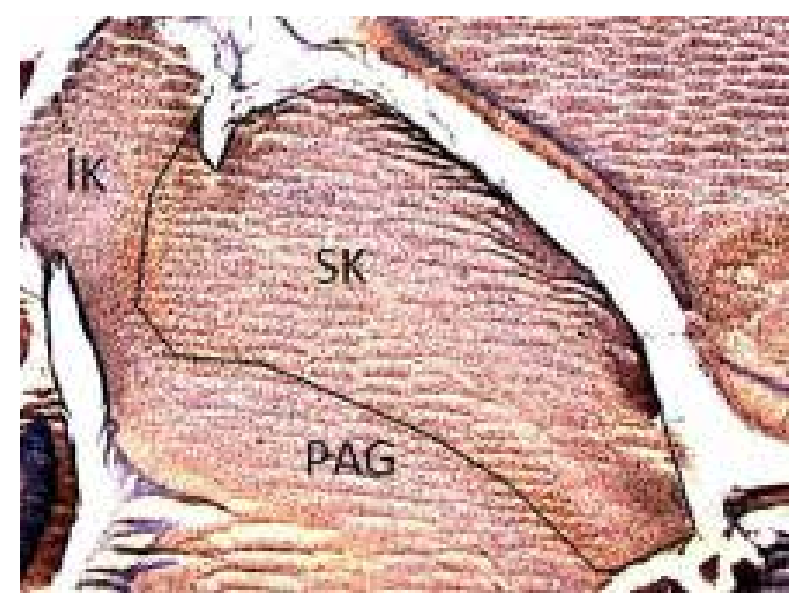

Fig. 1. General view of left superior colliculus in rat from control group seen in sagittal section. Area of inferior colliculus (IC), upper left, with periaqueductal gray matter (PAG) under superior colliculus (SC) is seen. volume of optical dissector probe (hdissector $\mathrm{x}$ aframe) (22 $008.93{\mu \mathrm{m}^{3}}^{3}$ ) were specified as indicated.

During cell count, the following characteristics of the neurons were taken into consideration. Cytoplasm of neurons is rich with Nissl bodies, and staining with cresyl violet causes cytoplasm to assume dark color. Nucleus of neuron remains unstained and takes on pale color.

Stereological analysis system used consisted of microscope (Olympus BX50; Olympus Corp., Tokyo, Japan), computer, color camera, and color video monitor. Images of sections were analyzed using CAST-Grid (Olympus Corp., Tokyo, Japan) stereological tool program.

Comparison between control group and group with epilepsy was performed using non-parametric Mann Whitney-U test and paired sample t-test. $\mathrm{P}<0.05$ was considered level of statistical significance.

\section{Results}

\section{Determination of superior colliculus area}

On sagittal section, gradual decrease in area of superior colliculus and structural changes were observed. In first sections, it was possible to discriminate between superficial and deep layers of superior colliculus as alternating areas of dark and light color, while in subsequent sections, it was impossible to discern layers as result of structural changes.

\section{Neuron samples counted in superior colliculus}

Small, medium, and large neurons were found in superior colliculus. Neurons were seen in clusters or in scarce numbers. It was not possible to make correlation between size of neurons and layer where found. Area of neuron count in control and epilepsy groups is presented in Figure 2.

\section{Total number of neurons found in the right and left superior colliculi}

Mean \pm SE number of neurons was calculated in the control group, right side was found to as $170404.4 \pm 14536.41$, and right side of epilepsy group count was found as 110 $335.4 \pm 6476.56$. Count of the control group on the left side was $148328.4 \pm 10305.48$, whereas count of the left side epilepsy group was found as $130103.1 \pm 5771.297$ (Table 1).

A statistically significant difference was found between the control right side and epilepsy right side $(p<0.05)$. A sta- 


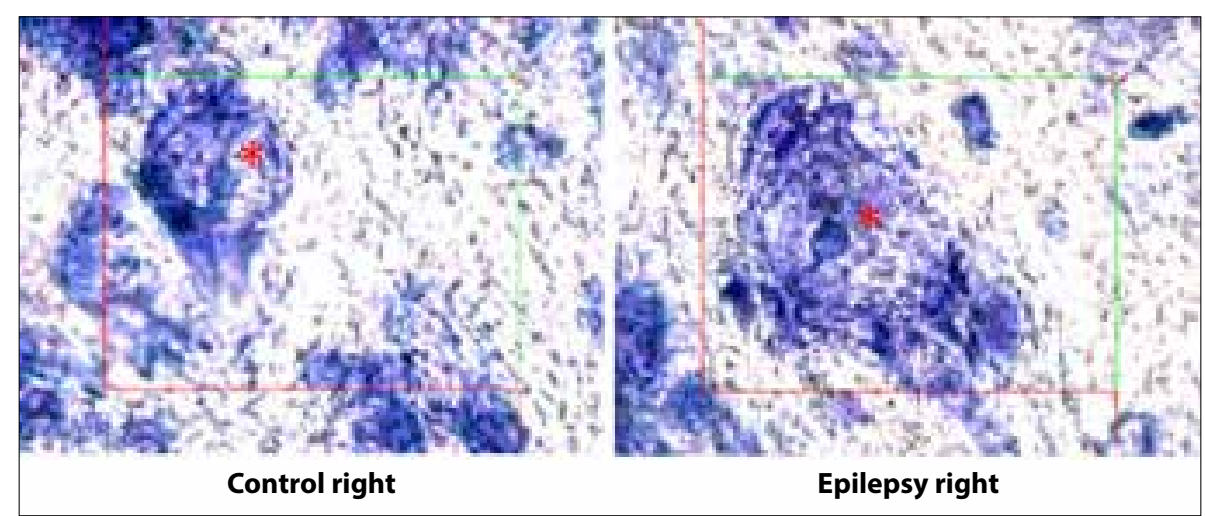

Fig. 2. EExamples of neurons counted in superior colliculus of animals from control and epilepsy groups (* indicates neurons). Area determined for neuron count in superior colliculus was magnified $100 x$ using immersion oil.

tistically significant difference was also detected between epilepsy right side and epilepsy left side $(p<0.05)$. However, statistically significant difference was not found on left side between control group and epilepsy group, or control group right side and control group left side ( $p>0.05)$.

\section{Discussion}

Studies performed with genetically audiogenic seizureprone animals have investigated 2 topics: brain structures that play different roles in audiogenic seizure, and whether cellular, biochemical, or physiological abnormalities exist in various brain areas of animals with genetic predisposition. ${ }^{[15]}$

In this study, fewer neurons were found in the right superior colliculus of genetically epilepsy-prone rats. In many studies cited in the literature, significant differences have been detected with respect to morphological and cellular characteristics of audiogenic animals. ${ }^{[16,17]}$ In a study performed with audiogenic Wistar rats, larger quantities of inflamma-

Table 1. Total neuron count of superior colliculi

\begin{tabular}{lc}
\hline Groups & Neuron count \\
\cline { 2 - 2 } & Mean \pm SD \\
\hline Control right hemisphere & $170404.4 \pm 14536.41$ \\
Epileptic right hemisphere & $110335.4 \pm 6476.56^{*}$ \\
Control left hemisphere & $148328.4 \pm 10305.48$ \\
Epileptic left hemisphere & $130103.1 \pm 5771.297$ \\
\hline
\end{tabular}

Total number of neurons in superior colliculi of rats from control and epilepsy groups and standard deviation values. *There was a statistically significant difference between epilepsy group right side and control group right side, and right and left sides of epilepsy group $(p<0.05)$. SD: Standard deviation. tory and neurotropic components were detected in the hippocampus, inferior colliculus, striatum, and cortex, therefore the role of predisposition to epilepsy has been suggested. ${ }^{[18]}$ In a study that investigated genetic predisposition to epilepsy, decrease in volume of deep layers of superior colliculus and neuronal hypertrophy were detected. ${ }^{[19]}$ Studies on inferior colliculus, which contains nucleus of audiogenic seizure activity, have demonstrated an increase in number of neurons demonstrating GABA activity accompanied with a decrease in GABA receptor levels. ${ }^{[20,21]}$ On the other hand, in a study performed with audiogenic seizure-prone Krushinsky-Molodkina rats, no difference in number of GABAergic neurons was detected in the inferior colliculus. However, 5 -fold increase in expression of glutamate decarboxylase messenger RNA, which plays a key role in GABA synthesis, was detected when compared with the control group. ${ }^{[22]}$ Data retrieved from these studies demonstrate that GABAergic system plays an important role in predisposition to development of audiogenic seizures.

Studies performed on audiogenic animals have indicated that onset of seizure activity is ipsilateral in motor area that represents active aspect of wild running behavior, while motor asymmetry seen in beginning of running behavior observed in audiogenic animals starts with lateralization on level of the brainstem. ${ }^{[23,24]}$ Electroencephalogram results obtained from audiogenic Wistar rats revealed that running behavior was more frequently directed to left side of the brain. Right hemisphere was more resistant to seizure activity, while the left hemisphere was more prone to this activity. In the same study, no hemispheric difference was detected in WAG/Rij rats regarding running behavior. ${ }^{[25,26]}$ Difference between hemispheres with respect to induction of seizure is 
not yet precisely known. It seems possible that epileptic activity spreads easily within right cortex or that epileptic discharges originating from brainstem spread between right and left hemispheres via different pathways. ${ }^{[26]}$

The present study supports results of studies that have detected hemispheric differences in epilepsy. A smaller number of neurons which were detected in the right hemisphere suggests that right superior colliculus demonstrates activation at the beginning, immediately before onset of audiogenic seizure with a greater intensity. Yet this does not explain the difference between hemispheres at the molecular level. In order to further clarify genetic predisposition to audiogenic epilepsy, additional studies at molecular level to determine layers and cell types in the superior colliculus responsible for number of neurons are required.

\section{References}

1. Garcia-Cairasco N, Terra VC, Doretto MC. Midbrain substrates of audiogenic seizures in rats. Behav Brain Res 1993;58(1-2):5767.

2. Ross KC, Coleman JR. Developmental and genetic audiogenic seizure models: behavior and biological substrates. Neurosci Biobehav Rev 2000;24(6):639-53.

3. Kai N, Niki H. Altered tone-induced Fos expression in the mouse inferior colliculus after early exposure to intense noise. Neurosci Res 2002;44(3):305-13.

4. Merrill MA, Clough RW, Jobe PC, Browning RA. Role of the superior colliculus and the intercollicular nucleus in the brainstem seizure circuitry of the genetically epilepsy-prone rat. Epilepsia 2003;44(3):305-14.

5. Raisinghani $M$, Faingold $C L$. Identification of the requisite brain sites in the neuronal network subserving generalized clonic audiogenic seizures. Brain Res 2003;967(1-2):113-22.

6. Faingold CL. Neuronal networks in the genetically epilepsyprone rat. Adv Neurol 1999;79:311-21.

7. Doretto MC, Cortes-de-Oliveira JA, Rossetti F, Garcia-Cairasco $N$. Role of the superior colliculus in the expression of acute and kindled audiogenic seizures in Wistar audiogenic rats. Epilepsia 2009;50(12):2563-74.

8. Rossetti F, Rodrigues MC, Marroni SS, Fernandes A, Foresti $\mathrm{ML}$, Romcy-Pereira RN, et al. Behavioral and EEG effects of GABAergic manipulation of the nigro-tectal pathway in the Wistar audiogenic rat (WAR) strain II: an EEG wavelet analysis and retrograde neuronal tracer approach. Epilepsy Behav 2012;24(4):391-8.

9. Faingold CL, Randall ME. Neurons in the deep layers of superior colliculus play a critical role in the neuronal network for audiogenic seizures: mechanisms for production of wild running behavior. Brain Res 1999;815(2):250-8.
10. Sakamoto T, Niki H. Acoustic priming lowers the threshold for electrically induced seizures in mice inferior colliculus, but not in the deep layers of superior colliculus. Brain Res 2001;898(2):358-63.

11. Rossetti F, Rodrigues MC, de Oliveira JA, Garcia-Cairasco N. Behavioral and EEG effects of GABAergic manipulation of the nigrotectal pathway in the Wistar audiogenic rat strain. Epilepsy Behav 2011;22(2):191-9.

12. Dailey JW, Jobe PC. Anticonvulsant drugs and the genetically epilepsy-prone rat. Fed Proc 1985;44(10):2640-4.

13. Gökçe FM, Bağırıcı F, Kaplan S, Demir Ş, Ayyıldız M, Marangoz C. A NOS inhibitor aminoguanidine reduces zinc-induced neuron loss in rat hippocampus, Neuroscience Research Communications 2003;33(1):53-62.

14. Kaplan S, Canan S, Aslan H, Unal B, Sahin B. A simple technique to measure the movements of the microscope stage along the $x$ and $y$ axes for stereological methods. J Microsc 2001;203(Pt 3):321-5.

15. Valjakka A, Jaakkola $M$, Vartiainen J, Olkkonen $H$, Semiokhina $A$, Fedotova I, et al. The relationship between audiogenic seizure (AGS) susceptibility and forebrain tone-responsiveness in genetically AGS-prone Wistar rats. Physiol Behav 2000;70(34):297-309.

16. Cardoso A, Madeira MD, Paula-Barbosa MM, Lukoyanov NV. Retrosplenial granular b cortex in normal and epileptic rats: $\mathrm{a}$ stereological study. Brain Res 2008;1218:206-14.

17. Repetto IE, Monti R, Tropiano M, Tomasi S, Arbini A, AndradeMoraes $\mathrm{CH}$, et al. The Isotropic Fractionator as a Tool for Quantitative Analysis in Central Nervous System Diseases. Front Cell Neurosci 2016;10:190.

18. de Souza Bernardino TC, Teixeira AL, Miranda AS, Guidine PM, Rezende G, Doretto MC, et al. Wistar Audiogenic Rats (WAR) exhibit altered levels of cytokines and brain-derived neurotrophic factor following audiogenic seizures. Neurosci Lett 2015;597:154-8.

19. Fuentes-Santamaría V, Alvarado JC, Herranz AS, García-Atarés $\mathrm{N}$, López DE. Morphologic and neurochemical alterations in the superior colliculus of the genetically epilepsy-prone hamster (GPG/Vall). Epilepsy Res 2007;75(2-3):206-19.

20. Roberts RC, Ribak CE, Oertel WH. Increased numbers of GABAergic neurons occur in the inferior colliculus of an audiogenic model of genetic epilepsy. Brain Res 1985;361(1-2):324-38.

21. Ribak CE, Lauterborn JC, Navetta MS, Gall CM. The inferior colliculus of GEPRs contains greater numbers of cells that express glutamate decarboxylase (GAD67) mRNA. Epilepsy Res 1993;14(2):105-13.

22. Solius GM, Revishchin AV, Pavlova GV, Poletaeva II. Audiogenic epilepsy and GABAergic system of the colliculus inferior in Krushinsky-Molodkina rats. Dokl Biochem Biophys 2016;466:32-4.

23. Ward R, Collins RL. Asymmetric audiogenic seizures in mice: a possible analogue of focal epilepsy. Brain Res 1971;31(1):207-10.

24. Pierson M. Audiogenic seizures in unilaterally sensitized and 
Epilepsi 2017;23(1):00-00

monaurally stimulated Wistar rats. Epilepsy Res 1992;11(1):1725.

25. Vinogradova LV, Shatskova AB. Lateral asymmetry of early seizure manifestations in experimental generalized epilepsy. Neu- roscience 2012;213:133-43.

26. Vinogradova LV. Interhemispheric difference in susceptibility to epileptogenesis: evidence from the audiogenic kindling model in Wistar rats. Brain Res 2010;1329:175-81. 